\title{
IPOSTAZE ALE LUI ULISE ÎN LIRICA LUI BLAGA, VORONCA ȘI SORESCU
}

\author{
Rebeca Murgu \\ rebeca.murgu98@e-uvt.ro \\ Universitatea de Vest din Timişoara
}

\begin{abstract}
This study is based on the analysis of the ancient Greek myth of Ulysses, which has been reproduced in various reinterpretations over time. However, the purpose of this paper is to highlight the myth of Ulysses in the vision of three important Romanian writers: Lucian Blaga, Ilarie Voronca and Marin Sorescu. To be more specific, the work will focus on the hypostases in which the protagonist of the Odyssey is outlined in the verses of these writers. We will notice during the research that, in the case of each writer mentioned above, Ulysses acquires personal nuances with an impressive note of originality.
\end{abstract}

Key words: hypostasis, intertextuality, myth, reinterpretation, Ulysses

Mitul lui Ulise constituie o referință recurentă întâlnită de-a lungul epocilor literare, fiind proiectat într-o varietate de opere, fie într-o manieră mimetică, fie într-un mod care se îndepărtează de textul epopeii antice. În acest sens, se remarcă o fascinație comună a scriitorilor din diverse perioade istorice și spații culturale manifestată față de această ficțiune homerică, atracție exercitată de silueta unui Ulise herculean învestit cu virtuți divine, care, înflăcărat de nostos, de revenirea la vatră, întreprinde o odisee fantastică și primejdioasă.

Periplul său de reîntoarcere în patria natală este presărat cu pericole iminente la fiecare pas, Odiseu, așa cum era numit de greci, fiind osândit după finalizarea războiului troian să rătăcească pe mare vreme de douăzeci de ani. Astfel, acest personaj este unul cu totul aparte, deoarece condiția sa damnată și eforturile supraumane prin care înfrună moartea care îl pândea în fiecare clipă îl fac vrednic atât de admirația contemporanilor săi, cât și de eternizarea figurii lui în conștiința populațiilor viitoare. Probabil, acesta este și motivul pentru care povestea lui Ulise este una de largă circulație, prezentă și în actualitate. Acest personaj a fost construit pentru a fi venerat, iar, prin nesfârșita și fluctuanta sa reelaborare în diferite ipostaze literare de-a lungul timpului, protagonistului Odiseei i se redă statutul glorios și valabilitatea istorică. 
Se întâmplă, însă, un lucru extrem de interesant începând cu epoca modernă, deoarece acum este momentul în care Ulise este prezentat cu calităţi distincte matricei arhetipale antice. Modernitatea și perioada literară ce îi succede extrage personajul homerian din valorizarea mitologică în care a fost încadrat de sensibilitatea clasică. Astfel, Ulise devine în modernitate omul simplu care rupe brusc legăturile cu transcendentul. El se dezice de credința în rugăciunile făcute muzelor și de laurul oferit de zei și se avântă în mijlocul mulțimii de dragul profanului pe care dorește să-1 privească drept în față, tânjind în carnea și duhul său să fie una cu lumea și să fie neîngrădit de orice dogmatizare care i-ar putea restricționa libertățile.

Prin această acțiune literară de reciclare a protagonistului Odiseei, într-o viziune insolită specifică doar lor, noile vârste literare nu doresc altceva decât să reactualizeze bornele canonice în jurul cărora a fost creionat legendarul Ulise. Așadar, Ulise este prelucrat prin mecanismele moderne și postmoderne și metamorfozat într-un personaj cu nimic mai presus de omul de rând. Se începe, astfel, ludica frondă faţă de literatura epopeică riguroasă prin conturarea unei imagini ̀̀ rebours a lui Ulise, personajul șablon al Antichității grecești fiind ilustrat prin felurite avataruri.

Literatura română nu face abstracție de acest fenomen expansiv de preluare a personajului mitologic, Ulise, având în vedere multitudinea textelor în care se regăsește protagonistul homeric. Interesați de devoalarea misterelor mitologiei, deci de desacralizarea ei, scriitorii români se afiliază trendului universal, cu cel mai acut ecou dat de Joyce, și pornesc în mișcarea revoluționară de reipostaziere a eposului grecesc. Probabil, cu atât mai exultanți în acest demers, deoarece literatura română simte plenar lacuna tragică a unui trecut epopeic celebru, cunoscut fiind faptul că noi ne formăm o literatură națională abia în secolul al XIX-lea.

$\mathrm{Cu}$ precădere, lirica românească modernă și post-modernă preia ipostaza emblematică a lui Ulise și o cartografiază într-o schiță portretistică inedită, conferindu-i nuanțe caracteristice dintre cele mai contrastante și neașteptate. Așadar, pornind din acest punct, lucrarea de față îşi dorește să ofere o selecție de ipostaze și aspecte ale lui Ulise, prezente în poezia românească de secol XX. Parcursul lucrării nu va fi strict cronologic, ceea ce ne interesează în final nu va fi evoluţia imaginii personajului mitologic în lirica românească la modul exhaustiv, ci dimpotrivă, oscilațiile caracterologice ale acestui protagonist legendar în viziunea a trei scriitori marcanți, Lucian Blaga, Ilarie Voronca și Marin Sorescu, ce au conferit acestei instanțe mitologice tușe dintre cele mai personale, chiar autobiografice. Vom remarca, de asemenea, importanța lui Blaga în ipostazierea personajului homeric, prin originalitatea pe care o imprimă unui Ulise reconstituit cu 
măiestrie poetică, Blaga marcând, totodată, parcursul sinuos al lui Ulise de la imaginea sa stereotipică înspre portretul stilizat sub amprenta individuală a scriitorului român.

Este cunoscut, deopotrivă, faptul că Lucian Blaga se distinge în literatura română prin fondarea masivă a creației sale pe situl mitologic, fiind preocupat în permanență de noțiunea de mister și de sacralitate, de transcendent și atingerea idealului cosmic. Astfel, Blaga găsește o oportunitate de a sonda în zona mitologică plină de reverberații metafizice prin intertextualizarea vechiului mit grecesc al lui Homer pe care îl înfățișează într-o manieră specifică în poemul său Ulise. Deși poemul păstrează relativ atmosfera eposului grecesc, poetul îi atribuie lui Odiseu ipostaze inedite ce se pretează pe sistemul său de gândire și poetică, valabilă în acest sens fiind afirmația pe care o face Mariana Șora în studiul său, Cunoaştere poetică şi mit în opera lui Lucian Blaga, și anume că ,Într-un sens, mitul, așa cum îl înțelege Blaga, e un mit degradat, fiind o invenție poetică personală” (191).

Blaga expune cu mult patos transfigurator mitul homeric în poemul său intitulat Ulise. Această operă lirică blagiană, inițial, are un soi de suflu solemn și eroic specific epopeii grecești, deschizându-se cu adresarea rece și rațională înspre soția sa Penelopa a unui Ulise resemnat, oarecum, cu condiția sa tragică. Într-un peisaj cufundat în tăcere, doar vocea lui Ulise se aude, străbătând aspru geografia expusă în poem. Toposul natural captează printr-un canal sinestezic acutizant zbuciumul conștiinței ,protagonistului” liric și îl reflectă ca într-un teatru catoptric: „De pe liman pe golfuri/ privirea ți-o rotește./ E liniște ca-n ziua/ când mă-ntorsei hoțește/ și ți-am golit de oaspeți/ viața, pragul, tinda./ Ia seama, Penelope,/ ce netedă-i oglinda.” (Blaga 329). Identificăm, așadar, o primă ipostază a lui Ulise care este și cea mai apropiată de cea originală prezentată în varianta lui Homer, și anume, aceea de războinic viteaz întors acasă tardiv și neașteptat și care restaurează haosul instituit în căminul său, făcându-și singur dreptate și reluându-și vechile atribuții de guvernare a casei sale, reafirmându-și, totodată, masculinitatea și drepturile conjugale asupra soției.

În acest îndemn al lui Ulise la meditație și supunere făcut soției sale, remarcăm, de asemenea, influența biblică a poemului blagian care prezintă același caracter profetic cu pildele biblice reproduse de Hristos, atunci când își învăţa discipolii despre Împărăția cerească care va să vie. La fel cum Hristos prevestește o revenire secretă a sa care va reînnoi pământul și cerul într-un demers apocaliptic, ,,personajul” poemului se întoarce în sânul familiei fără ca nimeni să știe acest lucru, instaurând o nouă ordine și dereticând tot ceea ce era nepotrivit din casa lui: ,și ți-am golit de oaspeți/ viața, pragul, tinda./ Ia seama, Penelope,/ ce netedă-i oglinda.” (Blaga 329). Putem 
identifica în acest pasaj liminar, după cum am observat, și o altă postură a lui Ulise care este precum un profet, ce aduce cu el o apocalipsă și, respectiv, o regenerare. Probabil această opțiune a lui Blaga pentru creionarea unei scene apocaliptice este datorată și influenței expresionismului.

A doua strofă a poeziei blagiene continuă și chiar aprofundează descrierea decorului. În acest spațiu, predominant este elementul marin ce guvernează întreg peisajul și care prezintă o încărcătură de semnificații mistice, după Mariana Șora: „elementul acvativ se instituie ca emblemă primordială a existenței și se oferă drept cale de imersiune în inima misterului cosmic" (140). Marea, prezentată aici într-o manieră gotică datorită recuzitei funeste, oase și reptile, constituie o zonă sinistră și riscantă, care face referire directă la moarte: „Se-ntinde marea clară/ pe-un prund de oseminte./ Nu-i nimenea cu prora/ s-o șteargă, s-o frământe./ Doar șerpii taie apa/ spre-un țărm ghicit în zare,/ trecând peste adâncuri/ ca semne de-ntrebare.” (Blaga 329). Este sesizabilă, așadar, o însingurare dezolantă și sepulcrală ce domină această topografie care propagă o multitudine de interogații lansate în neant fără așteptarea unui răspuns concret. Așadar, marea care reprezintă o zonă ofertantă pentru spiritul aventurier al lui Ulise este în același timp și spațiul care îl confruntă direct pe personaj cu sentimentul vulnerabilității și al morții: „peisajul marin se proiectează ca realitate stranie sau ca irealitate firească în fața căreia ființa contemplă miracolul extincției” (Fanache 148). După cum putem observa, componentul marin are o importanță definitorie în acest poem și merită un studiu mai aprofundat, însă atenția noastră va continua să se îndrepte înspre taxonomia lui Ulise.

Întors din tragica și îndelungata lui rătăcire, Ulise rememorează cu durere profundă infernul depărtării de casă, folosindu-se de cele mai tulburătoare imagini: „Catargul putrezește/ la margine de timp/ acolo între Hades/ și-cele culmi în nimb.” (Blaga 329). Cu conștiința omului greu încercat de destin, Ulise învață din greșelile urmate de lăcomie și ispitire: „Nu m-amăgește ceasul/ să număr nestemate,/ nici nu mă cheamă-n urmă furtuni și vrăji uitate.” (329). El este capabil acum să dea sfaturi înțelepte celorlalți, dat fiind faptul că a înfruntat victorios ororile alienării și astfel a dobândit învăţături de viață ,,prin țări, prin ani primite,/ pe la răscruci și vămi” (329).

În finalul poemului, demersul liric ia, însă, o întorsătură implacabilă, aceea a retragerii în tăcere și din această hotărâre a lui Blaga de a-și motiva ,personajul” înspre acceptarea tăcerii ca însuși mod de viață decurge cea mai semnificativă ipostază a lui Ulise din poemul blagian și anume aceea a unui Ulise mut. Blaga își amuțește ,,personajul” și îl mântuie de durerile trecutului prin retragerea în sfera sterilă a nerostirii. Ulise renunță la discursul său care îl consacră și se lasă compleșit de liniște și amnezie curativă. În această cheie interpretativă, putem afirma împreună cu 
Eugen Todoran că în acest poem blagian mitul lui Ulise este ,reinterpretat poetic într-o nouă odisee, cu sensul aventurii limbajului în actul poetic, ca act semnificativ în strategia comunicării” (184).

Putem afirma că atracția lui Blaga pentru liniște este un reper omniprezent în creația lirică a scriitorului, ea fiind poziţionată sub zodia tăcerii. Pentru a întări această convingere, reținem că această particularitate a poemelor lui Blaga a fost remarcată de critică de-a lungul timpului, iar Vasile Fanache afirmă că „opțiunea pentru arta tăcerii este susținută de Blaga cu o pasiune doctrinară ieșită din comun, din convingerea că drumul poeziei a încetat să fie exclusiv drumul cunoașterii" (7). În altă parte a studiului său, criticul explică fascinația poetului pentru necuvânt, prin aforismul ce furnizează o definiție viabilă a literaturii moderne: „Logosul modern tace” (15). Așadar, prin abordarea afaziei, Ulise este pregătit să contemple frumusețea și moartea și să aspire, astfel, spre alte niveluri ale cunoașterii: „Dar pe liman ce bine-i să stăm în necuvânt - / și, fără deamintire/ și ca de subt pământ ,/ s-auzi, în ce tăcere/ cu zumzete de roi,/ frumusețea și moartea/ lucrează peste noi." (Blaga 330).

Tot din această ipostază definitorie a lui Ulise, portretizat ca un spectator mut în faţa tainicelor prefaceri cosmice, decurge un ego secundar al „personajului” care se referă la natura filozofică a lui, deci este cartografiat aici un Ulise filozof. Într-o descriere oximoronică a senzațiilor auditive ce îl năpădesc pe Odiseu, printre zumzetul de sonorități silențioase ale morții și frumuseții care acționează în afara și în interiorul ființei umane (,s-a-auzi, în ce tăcere/ cu zumzete de roi/ frumusețea și moartea/ lucrează peste noi”), Ulise este angrenat într-un proces intens de contemplare a unor noțiuni absolute, ca frumusețea și moartea, ultima reprezentând, de altfel, însăși o marcă a tăcerii, dar în acest caz, o tăcere eternă și iremediabilă. Această ipostază este sesizată și de Ion Pop care îl poziționează pe Ulise, în lumina acestor fapte, între două tropice definitorii ale cunoașterii: iubirea și moartea, exegetul remarcând că prin această manieră de creionare a lui Ulise scriitorul însuşi ,pare a fi găsit, între ipostaza supremei arderi a ființei stăpânite de eros și aceea a omului aflat la capăt de aventură existențială, expresia calmei împăcări cu logica firii, care presupune în egală măsură sacrificiul de sine și împlinirea" (106).

Opțiunea pentru densitatea epică a epopeei grecești transpusă în registrul liric se regăsește și la Ilarie Voronca, scriitor român al avangardei și teoretician al acestor formule, care celebrează, de asemenea, mitul homeric în opera sa Ulise, publicată în 1928 la Paris, volum însoțit de un desen realizat de pictorul evreu Marc Chagall. Voronca ilustrează o altă ipostază a lui Ulise, în care amprenta autobiograficului este evidentă. 
În poemul cu accente suprarealiste, Ulise este înfăţișat ca un alter ego al scriitoului, Ilarie Voronca, ce odată ajuns în luminoasa și moderna metropolă pariziană se lasă vrăjit de mirajul mașinilor și al tehnologiei marelui oraș, așadar: „Voronca, sub aspectul unui modern Ulise, se perindă prin piețele Parisului” (Iancu 9). În acest poem, Ulise este emigrantul evreu ce se aciuează în faimoasa capitală a Franței, oraș în care fuge din calea asupririlor pe care este nevoit să le îndure pe teritoriul român, datorită acțiunii antisemite ce ia amploare din ce în ce mai mult. Așadar, Ulise întruchipează acum poetul modern care suferă nedreptăţi aspre într-o societate ostilă, iar descrierea lui Ilarie Voronca a poetului avangardist din manifestul Cicatrizări. Poezia nouă i se potrivește cu desăvârșire acestui personaj prototipic: „Poetul nou e un explorator înfruntând meridianul cel mai primejdios, coborând în însuși miezul înțelegerii, ecuator încins sau pol cu zăpezi ca bretele. Pe umerii lui preerii cresc. Stepe, mări, saltimbanci, trenuri îi circulă în artere" (Cicatrizări 3).

Remarcăm, astfel, un Ulise rătăcitor nu pe o fâșie maritimă primejdioasă, ci într-un spațiu citadin atins de obsesia automatizării. Viziunea suprarealistă a interiorului uman înfăţișează locuitorii metropolei într-o manieră decadentă și pragmatică. Ei nu-și mai doresc un contact cu natura primitivă: „,brațele noastre nu mai sângeră păduri sălbatice” (Voronca, Ulise 15), ci își ocupă timpul cu obiceiuri mercantile, care îi îndepărtează de valorile umane: ,singuri ne închidem în mucegaiul birourilor/ dimineața dactilografele își îmbrățișează logodnicii/ până la revederea în ceasul nopții” (15), toate acestea întâmplându-se într-un Paris în care supurează lumini artificiale: „pe bulevarde sirenele autobuzelor/ cum acompaniază concertul prin fără fir” (15), într-un ,,veac al asigurărilor și al reclamei luminoase” (15).

Voronca își eliberează havuzurile imaginației și animă invenții miraculoase în această lume pariziană pe care scriitorul o percepe într-un mod fabulos prin alăturarea nestingherită de obiecte divergente. Fiind un alchimist al obiectelor cotidiene, în aparență banale, Voronca realizează o frescă suprarealistă prin excelență, în care lucrurile nu se mai identifică cu eticheta și nu mai folosesc întrebuințării uzuale. De pildă, „precupeții ridică obloanele somnului” (15), „tramvaiele lăptăresele autobuzele își acordează ca o orchestrație/ instrumentele” (15), urmând ca apoi peisajul exterior să fie înlocuit de interioarele la fel de deconcertante în ceea ce privește logica firească a lucrurilor: „ca o cupă la locul lor pulpele intestinele/ obrazul se desprinde ca un perete/ buzele buzele cu surâsul pantofilor/ și încheieturile de vată/ încet te tragi pe tine din tine însuți” (16).

Puterea creativă a lui Voroca se declanșează exploziv, nefiind îngrădită de nicio limitare, astfel nu ne mai miră nici faptul că poetul nu se sfiește să dedice ode lungi și măgulitoare ceaiului 
sau cartofului și chiar să realizeze o clasificare a oglinzilor: „oglinzi de culoarea tăcerii a surâsului/ oglinzi ca peștele zvărcolindu-se în metal/ oglinzi ca o amintire a văzduhului” (27) ș.a.m.d. Am putea spune că atât de uimit este Ulise în descoperirea Parisului, încât chiar și celor mai banale obiecte, în viziunea lui, le e conferită o alură misterioasă și insolită.

Totuşi, dorul de casă este nelipsit din această călătorie, așadar, putem afirma că regăsim o altă ipostază a ,personajului” poemului, și anume un Ulise nostalgic, care e simptomatic pentru formula identificată de Nicolae Balotă în legătură cu condiția paradoxală a poetului, care își negociază identitatea prin ,fugă de sine și cucerire de sine” (170). El își amintește de Brașov și se proiectează cu ajutorul puterii nebănuite a memoriei în spațiul românesc plin de legende și armonii naturale: „,iată-te la brașov cum iubești străzile lui drepte/ PĂDUREA E aproape și liniști mari îți ling gleznele" (36), în acest loc fabulos în care divinul coboară în mundan și este prezent ca întrun Eden binecuvântat: „,e dumnezeu care trece gârla văzduhului pe bolovani de luceferi” (36). Braşovul protejat de falnicii munți este descris într-un registru inedit stilizat cu metafore vibrante și plasticizante: „brașov cetate cu pereți oglinzi în munți/ pieptul tău e deschis la sulițele aerului/ anotimpurile îți aduc buchete de șipote/ tăcerea e ca o cireașă își suie coarnele până la tine” (37), urmând ca, mai apoi, această imagine să se estompeze în fluxul epitetelor și al imaginilor halucinante, iar în finalul poemului să regăsim imaginea Parisului din versurile incipiente, redând circularitatea operei și justificând afirmația lui Voronca din manifestul său Cicatrizări. Poezia nouă, și anume: „Orice vers e o sumă de noi posibilități, o altă soluție a ecuației primare” (3).

Ecuația lui Ulise nu se încheie în lirica din prima parte a secolului XX, ci își revelează posibilităţile și ulterior. Revenind la poemul blagian Ulise și analizându-1 într-o manieră comparatistă cu poezia omonimă Ulise, scrisă de Marin Sorescu, putem observa facil și transparent cum registrul oarecum solemn și criptic folosit de Blaga în poezia sa se dizolvă într-o ironie ce atinge cote majore în poemul sorescian și astfel ne este furnizată o altă ipostază a personajului homeric, un Ulise sarcastic și zeflemitor. La Sorescu, Ulise s-ar putea dezice cu ușurință de gândul reîntoarcerii acasă, deoarece îi este lehamite de haosul instituit împrejurul soției sale, Penelopa. Fără nicio reținere, Ulise îi insultă caustic pe pețitorii Penelopei: „Porcii aceia de pețitori,/ Beți chiori, slinoși pe armurile din cuier/ Jucând toată ziua table/ Până li se înmoaie și mușchii și zarurile,/ de-a valma,/ Că numai de însurătoare nu mai sunt buni/ Chiar de-ar cere în căsătorie o babă" (639), Ulise ducându-și revolta mai departe, insultând-o pe propria soție pe care o face întrun elan tăios: „o babă/ Mai ceva decât Penelopa” (639). 
Discursul acid al lui Ulise se continuă în a doua strofă a poemului sorescian, unde ,personajul” liric aduce invective aspre la adresa Penelopei, de care se îndepărtează afectiv prin folosirea demonstrativului din sintagma „Și femeia aceea” (639) și căreia îi atribuie însușiri triviale: ,plângăreață, pe de altă parte,/ Care țese-n neștire, de nervi,/ De zripțuroaică ce este, să încurce ea toate/ firele de pe lume!” (639). În aceeași octavă este descrisă și eventuala primire rece și cicălitoare a soției sale care, în cazul în care acest Ulise caricatural s-ar reîntoarce acasă, i-ar adresa următoarea întrebare plină de sarcasm: „Unde-ai putut să fii acum?” (639). Ulise ricoșează aici cu insolență: „Am făcut războiul Troii, nu fii scorpie...” (639).

Varianta soresciană a lui Ulise se îndepărtează extrem de mult de cea a lui Blaga prin faptul că, pe când Blaga îi conferă o aură filozofică ,ppersonajului”’ său care se retrage în tăcere împins de dorințe nobile de experimentare a stărilor contemplative, la Sorescu întâlnim doar un individ saturat de intimitatea propriului cămin conjugal, și care printr-un oftat plictisit își expune planul de sustragere din această situație nefavorabilă lui, și anume acela de a-și construi un adăpost în singurătatea mării îndepărtate: „Of, să-mi fac o căsuță/ Aici pe valuri,/ Să-mi ridic un cort în colțișorul ăsta/ Mai ferit/ Între Scyla și Caribda.” (640).

Pe de altă parte, dacă privim în paralel figura eroului la Voronca și Sorescu, putem remarca poziția antinomică a celor doi Ulise, care se regăsesc în două ipostaze complet opuse în cele două opere literare. La Voronca, Ulise întruchipează intelectualul rătăcitor în căutarea unui sens existențial în universul urban, în timp ce Ulise creionat de Sorescu devine un personaj provincial, ce aduce cu un aborigen al satului românesc, care nu își dorește altceva decât o viaţă tihnită în mijlocul naturii. Coborârea în cotidian este prezentă la amândoi, dar la Sorescu prozaicul intenționat, tenta aproape parodică nu exprimă fronda vehementă față de existent: „Sorescu înviorează temele mari, le face simpatice, fără să le depoetizeze cu adevărat” (Manolescu 1035).

În concluzie, mitul lui Ulise reprezintă o sursă inepuizabilă de inspirație pentru acești scriitori români care îl înfățișează pe protagonistul Odiseei într-o variate de ipostaze și contexte artistice. Analizând textele omonime Ulise ce aparțin lui Lucian Blaga, Ilarie Voronca și Marin Sorescu, am putut sesiza în dreptul fiecărui scriitor manierele personale de construcție lirică a acestui personaj canonic. De pildă, în poemul blagian (cel mai apropiat de fondul mitologic) ceea ce importă este puterea de control al actului vorbirii, Ulise fiind un martor silențios în fața miracolelor ce îi robesc gândirea: frumusețea și moartea. În schimb, Voronca și Sorescu nu mai păstrează nimic din potențialul tăcerii, la ei Ulise devine vocal, lucid sau chiar hiperlucid. Voronca își transpune propria persoană în creația sa, percepându-se pe sine ca pe un Ulise rătăcitor într-un 
peisaj citadin nefamiliar. Însă esențială rămâne la el ancorarea universului poetic în mecanicism, mercantilism. În același timp, la Sorescu remarcăm banalitatea, ,familiaritatea tratării unor teme filosofice" (Manolescu 1033) asamblarea personajului emblematic Ulise are un rezultat caricatural, apropiindu-se mai mult de un model (folcloric) românesc decât de cel grecesc.

Prin urmare, întregind rândurile scriitorilor europeni, cei trei reprezentanți români asupra cărora ne-am abătut atenția critică realizează un joc intertextual abil prin care reciclează personajul homeric, reactualizându-1 și aducându-1 mai aproape de sensibilitatea actuală: „dacă zgâriem cu unghia stratul de deasupra, constatăm că realitatea aceasta zilnică e un decor de carton montat grijuliu pe o scenă de teatru, pe care se desfășoară un spectacol de mult cunoscut, cu personaje mitice, ale căror replici răsună de mii de ani în urechile culturii europene” (Manolescu 1034).

\section{Bibliografie:}

Balotă, Nicolae. Arte poetice ale secolului XX. Ipostaze românești și străine. București: Editura Minerva, 1976.

Blaga, Lucian. Opera poetică. Cuvânt înainte de Eugen Simion, Prefață de George Gană, Ediție îngrijită de George Gană și Dorli Blaga. București: Editura Humanitas, 1995.

Fanache, Vasile. Chipuri tăcute ale veșniciei în lirica lui Blaga. Cluj-Napoca: Editura Limes, 2007.

Iancu, Carol. „Ilarie Voronca - poet al modernității și al iubirii”. Apostrof, an XXII, no. 6 (253), 2011, pp. 7-12, http://revista-apostrof.ro/apowp/reviste/2011-06.pdf. Accesat 25 oct. 2020.

Manolescu, Nicolae. Istoria critică a literaturii române. 5 secole de literatură. Pitești: Editura Paralela 45, 2008.

Pop, Ion. Lucian Blaga - universul liric. București: Editura Cartea Românească, 1981.

Sorescu, Marin. Opere. Vol. I: Poezii. Ediție îngrijită de Mihaela Constantinescu-Codocea, Prefață de Eugen Simion. București: Fundația Națională pentru Știință și Artă, Editura Univers Enciclopedic, 2002.

Șora, Mariana. Cunoaștere poetică și mit în opera lui Lucian Blaga. București: Editura Minerva, 1970.

Todoran, Eugen. Lucian Blaga. Mitul poetic. Volumul I. Timişoara: Editura Facla, 1981. Print.

Voronca, Ilarie. „Cicatrizări. Poezia nouă”. Integral, an 1, no. 4, 1925, pp. 2-3, http://dspace.bcucluj.ro/bitstream/123456789/64232/1/BCUCLUJ_FP_279547_1925_001_0 04.pdf. Accesat 29 oct. 2020.

---. Ulise. Brățara nopților. Cluj-Napoca: Editura Dacia, 2003. 